УДК 355.43:94(100) «16»

ВОЙТОВИЧ Л.В.

https://orcid.org/0000-002-9191-6537

https://doi.org/10.33577/2313-5603.32.2019.17-32

\title{
ВІЙСЬКОВА ДІЯЛЬНІСТЬ КНЯЗЯ КОСТЯНТИНА ІВАНОВИЧА ОСТРОЗЬКОГО
}

Стаття присвячена оцінці військової діяльності князя Костянтина Івановича Острозького, перш за все як полководця. Розглядаються головні перемоги, здобуті під його командуванням, зокрема під Оршею (1514) та Каневом (1527). Звернена увага на спроби сучасної російської історіографії применшити роль i здобутки Костянтина Острозького як полководця. Обгрунтована гіпотеза стосовно ролі князя у формуванні раннього козацтва.

Ключові слова: Костянтин Іванович Острозький, полководець, Орша, Канів, козаки.

Постановка проблеми. Українська військова історія робить тільки перші кроки свого становлення. “Доганяючи” в дослідженні цих проблем своїх сусідів, українські дослідники не завжди встигають заперечувати навіть свідомі фальсифікації. Через це і постаті полководців українського походження залишаються десь на маргінесі або ж займають гідне місце в шеренгах видатних діячів сусідніх держав і народів. Значущість того чи іншого військового діяча визначається перш за все відповідністю результатів його діяльності рівню епохи, в якій ця діяльність відбувалась, засвоєнню і практичному втіленню передових ідей цієї епохи, а також кінцевих наслідків цієї діяльності.

3 численних сутичок і битв, як проміжних, так і вирішальних для долі кампаній або й цілих війн, кожне століття виокремлює менше десятка битв, які мали вплив на подальший розвиток військового мистецтва або своїм враженням на сучасників зберегли за собою довгу пам'ять. Примхливість військової долі, коли успіх залежить від великого масиву факторів, призводить до того, що рідко якому полководцеві вдавалося здобути хоча б десяток великих перемог. Всі ці критерії застосовуються світовою військовою наукою при оцінці полководців, тоді як українські, і почасти російські, дослідники розглядають такі особистості ізольовано не тільки від

Войтович Леонтій Вікторович, доктор історичних наук, професор, завідувач кафедри історії середніх віків і візантиністики Львівського національного універсритету імені Івана Франка, м. Львів.

(С) Войтович Л. В., 2019 
світового чи загальноєвропейського контексту, але й без порівняння $з$ основними сусідами та противниками.

Iсторіографія теми. Князю Костянтину Івановичу Острозькому $(1450$ - 1530), перш за все як політикові та одному з лідерів Великого князівства Литовського, який підтримував місцеві традиції та православ'я, присвячена достатньо велику кількість літератури (Paprocki, 1858:448, Niesiecki, 1841:179-189, Перлштейн, 1852:33-48, Genealogia doти Ostrogskich, 1871:128, Голубев, 1877:182-191, Романовский, 1878:205-209, Петрушевич, 1879:50-71, Петров, 1879: 79-81, Rulikowski, 1880:195,3-40, Boniecki, 1883:220-239, Wolff, 1895:342-351, Ярушевич, 1896:250, Голубев, 1877:457-461, Быков, 1915:60, Lewicki, 1938:1-66, Зноско, 1933:290, Charkiewicz, 1934:240, Herbst, 1949:3-68; Ochmański, 1960:349-398, Dundulis, 1971:219, Wojtkowian, 1979:486-489, Войтович, 1996:355367, Войтович, 2011:52-62, Ульяновський, 1995:24-31, Ковальський, 1899:288, Мицько, 1999:49-56, Мицик, 2000:133 - 137, Яковенко, 2002:150,163, 237-286, Кетра, 2003:194, Кулаковський, 2011:67-83). Серед останніх праць зазначимо грунтовні дослідження Василя Уляновського (Стрийковський, 1992:112-121, Ульяновський, 1995:24-31, Ульяновський, 2009:168). У цих працях дослідники, оцінюючи князя Острозького як полководця, здебільшого просто переказують захоплені оцінки сучасників, які називали його “руським Сципіоном”, порівнюючи 3 відомим римським полководцем, який здобув Карфаген, а також Олександром Македонським, Пірром та іншими визначними полководцями. і перелічують число битв, взятих з епітафії.

В. Уляновський спробував переглянути усталену оцінку князя Костянтина Івановича Острозького як полководця, висловивши певні сумніви, перш за все в числі битв і перемог (Ульяновський, 1992:112-121, Ульяновський, 1995:24-31). Згодом історик переглянув свою позицію, хоча сумніви його повністю не розвіялися "наша оцінка не має жодного значення, оскільки головним $\epsilon$ сприйняття кн. К. I. Острозького його сучасниками та нащзадками" (Ульяновський, 2009:80). Проблема оцінки військової діяльності князя і далі залишається дискусійною, а, отже, і актуальною.

Метою наукової розвідки є аналіз військової діяльності князя Костянтина Івановича Острозького. 
Виклад основного матеріалу. Захоплені відгуки та свідчення сучасників, зокрема короля Сигізмунда I, давно широко цитовані в історичній літературі (Ульяновський, 1995:26). Зупинимося на трьох свідченнях зовсім різних авторів, які не мали особливих підстав так високо піднімати авторитет князя Острозького.

Для сучасника легата римського папи у Польщі кардинала Пізоні, князь К. І. Острозький мав одну вагому ваду - він був схизматиком, тобто православним, і прославляти його подвиги потреби не було, скоріше навпаки. Однак в листі 1514 р. легат писав: “Князь Костянтин може бути названим кращим воєначальником нашого часу, він 33 рази ставав переможием на полі битви.. в бою він не поступається хоробрістю Ромулу" (Домбровский, 1840:88-89). Князь Андрій Курбський (1528 - 1583), добрий і досвідчений полководець, оцінював князя К. І. Острозького як “гетьмана хороброго i славного... яко славний $і$ похвальний в діяннях ратних себе показав, батьківщину свою обороняючи" (Максимович, 1866:19). I, нарешті, Шимон Старовольський $(1588$ - 1650) у своїх біограмах сарматських полководців (1631), куди він вносить цвіт польського воїнства, подає таку оцінку схизмата і руського князя К. І. Острозького: "Муж сильної руки, з великим розумом та іншими достоїнствами, який не мав рівних собі серед сучасників. Був воӥном видатним. Тридиять три рази здобував він перемоги, завжди отримуючи славні тріумфи над ворогами Батьківщини. Це преславний вождь, під чиїм командуванням здобуто славні на цілому світі перемоги над Москвою під Оршею, над Татарами під Каневом. 3 иьього поводу він єдиний тільки з усіх вождів польських відбув тріумф у Відні і в Кракові. Був то славний майстер військового мистецтва в Сарматії..." (Starowolski, 1978:184-187).

Всі сучасники і дослідники одностайні в тому, що найбільшою перемогою князя К. І. Острозького була перемога у битві під Оршею 8 вересня 1514 р. Що було в цій битві незвичного, що відрізняло іiі від великої кількості інших битв цього і пізніших часів? Битва достатньо добре досліджена у військовій літературі (Быков, 1915:309-327, Górski, 1890:85-98, Каспровский, 1899:112-118, Herbst, 1949:33-68, Spieralski, 1965:331-337, Мицик, 2000:122-137, Nagielski, 2015:242) і подавати ще раз ії перипетії немає потреби.

Раніша російська історіографія визнавала, що у військах князя Михайла Івановича Голіци-Булгакова (1466 - 1558) та боярина Івана Андрійовича Челядніна (+1521) було 80 тисяч бійців, тоді як у 
князя К. І. Острозького - не більше 30 тисяч (Соловьев, 1989:239). 3 визначенням чисельності війська великого гетьмана литовського князя К. І. Острозького простіше. За Сигізмундом фон Герберштейном (23.08.1486 - 28.03.1566), який двічі побував у Москві як імперський посол $(1517,1526)$, литовсько-польське військо мало не більше 35 тис. проти 80 тис. московського війська, але воно мало артилерію (Герберштейн, 1988:70). За Станіславом Сарніцким (бл. 1532 23.09.1597), військо К. І. Острозького мало 12 тис. литовської кінноти, 2 тис. важкої польської кінноти і 3 тис. найманої піхоти, тобто 17 тис. (Sarnicii, 1587:385-386). За Мацеєм Стрийковським (21.03.1547 - 1593), все військо мало 25 тис. осіб (Стрийковський, 2011:898). Його основу складали 16 тис. кінноти надвірних військ українських, білоруських і литовських князів і магнатів: самих Острозьких, слуцького князя Юрія Семеновича Олельковича (1492 - 1542), київського воєводи Юрія Радзивіла на прізвисько Геркулес (бл. 1480-1541), господарського писаря Івана Богдановича Сапеги (близько 1480 - 1546) та ін. Польську допомогу очолював теребевельський староста Ян Сверчовський (+ 1528) (Starowolski, 1978:192-193). Це теж була важка і легка кавалерія, основу якої складали дружини Тенчинських, Пілецьких, Кмітів, Зборовських і польські гусари Петра Мишковського, який близько 1500 р. виступив організатором цього різновиду кінноти (Солдатенко, 1993:17-24). Борис Черкас оцінив польську складову війська у 5 тис. важкої кавалерії, 3 тис. найманої сілезької піхоти та 5 тис. ополченців, тобто бл. 13 тис. (Черкас, 2011:81) Враховуючи складнощі з мобілізацією і розгортанням війська та інші важливі моменти, можна погодитися 3 підрахунками Олексія Лобіна, який вважав загальну чисельність війська рівну 16 тис., 3 яких король залишив під Борисовом 4 тис. Тобто в битві у війську К. І. Острозького було 12 тис. осіб (Лобин, 2010:18-43, Лобин, 2010:111-113).

Складніше визначити чисельність московського війська. 80 тис. вказав польський король Сигізмунд Старий у листі до папи Лева $\mathrm{X}$ Медічі, який був надрукований в Римі у тому ж 1514 p. (Acta Tomiciana, 1853:nr. 232) 3 цим погоджуються ряд дослідників з різних країн (Strahl \& Hermann, 1846:22, Гриикевіч, 1993:187, Грииякевіч, 2005:249, Lindner, 1999:89, Волков, 2004:57). Але ця чисельність, безперечно, завищена (Зимин, 1972:64). Однак прийняти підрахунки російських дослідників, які намагаються зменшити розміри російських військ до 12 тис. (Лобин, 2009:66, Марков, 2007:79-90, 
Пенской, 2009:91-103, Курбатов, 2009:104-119, Лобин, 2009:121-126), тобто зрівняти їх чисельність з військом К. І. Острозького, звичайно, не можна. Метод, запропонований О. Лобіним, на перший погляд, виглядає коректним (спираючись на матеріали Полоцького походу 1563 р. і виходячи з мобілізаційних можливостей волостей, звідки набиралися ратники Голіци-Булгакова і Челядніна, він згадує гіпотетичні 7200 дворян). Але далі дослідник довільно виводить число служилих татар у 400-500 осіб, а число бойових холопів 5400-7400 осіб і отримує загальне число 13 - 15 тис., зменшуючи ïх до 12 тис. за рахунок відправлених з естафетами сеунчів, (Сеунчі, від татар. - радісна, переможна звістка - посланці воєвод 3 переможними реляціями, вирушали у супроводі не більше десятка осіб і, зрозуміло, поверталися назад (Сороколетов, 1970:255). Однак число холопів було щонайменше у 2-3 рази більшим за число дворян (див., наприклад: (Середонин, 1891:32). За спостереженнями Річарда Хеллі московські дворяни приводили в середньому 3,3 холопів на особу, жильці 3 провінції - 1,13. Див: (Хэлли, 1998:712). Згідно розпису 1604 р. 507 дворян виставили у повному озброєнні 2252 кінних холопів. Див: (Мордовина \& Станиславский, 1979:245-247, Скрынников, 1986:35), підрахунок яких також явно підігнаний, навіть без врахування того, що ситуація 1514 р. була значно сприятливішою для московського війська ніж ситуація 1563 р. Більш коректними видаються підрахунки американського дослідника Девіда Л. Сміта, який приймав чисельність московського війська до 35 тис. осіб (Smith, 1993:38). Але ця чисельність була не меншою ніж 30 тис. осіб (Войтович, 2017:765).

Звичайно, як і всі великі битви або більшість 3 них, битва під Оршею визначалася сприятливим для князя Острозького збігом обставин: місництво і взаємна ненависть головних московських воєвод вплинули на кінцевий результат. Але блискучий маневр 3 центру та правого флангу на лівий перед очима противника, як $\mathrm{i}$ зворотній маневр у другій фазі битви 3 лівого флангу в центр безперечна заслуга великого гетьмана литовського К. І. Острозького, який керував ходом битви, не випускаючи ініціативи з рук. Велику роль відіграло і масоване застосування вогнепальної зброї, з чим московське військо у польовій битві зіткнулося практично вперше. Заманивши противника імітованим відступом під залпи своєї артилерії, наслідки яких були жахливими, князь Острозький зламав волю противника до продовження битви. 
У листах до європейських володарів король Сигізмунд Старий повідомляв, що московські втрати склали близько 30 тисяч вбитими, пораненими і полоненими, причому в полон потрапили 6 верховних воєвод, 37 воєвод меншого рангу і 1500 дворян (Acta Tomiciana, 1853:nr. 232, 288, 289, 293, 295, 298, 301). У листі до гнєзненського архієпископа і примаса Польщі Яна Ласького (1455 - 1531), який перебував у Римі на Латеранському соборі, король зазначив, що у битві загинуло 16 тис. московитів (Acta Tomiciana, 1853:nr. 234).

Зрозуміло, що ці втрати перебільшені, але вони справді були приголомшливими. 311 верховних воєвод 6 опинилися в полоні, а двоє загинули (князь Іван Темка-Ростовський і князь Андрій Оболенський-Пенінський). За поіменним реєстром 1519 р., в полоні перебувало 611 московських дворян (Регистрь и имена всих вязенеи московских, где который, в которомъ замъку седять по Великому князьтву Литовскому (1519. 03.24) (Дубонис, 1997: 87-92). Зрозуміло, що до цього часу частина померла, декому вдалося втекти чи викупитися, інші опинилися на польських землях, а частина не потрапила до реєстру. За російськими підрахунками, в полон потрапило 380 дворян (Зимин, 1972:165-166), але ці підрахунки не повні. Підрахувати точне число загиблих неможливо, але у родинних пом'яниках чи розписах багатьох князівських родин є вказівки на загиблих під Оршею.

Великі втрати московського війська мають своє пояснення. 24 лютого 1525 р. при Павії імператор Карл V розгромив французьке військо. Долю битви вирішили залпи аркебузерів, причому один постріл виводив зі строю одразу кілька людей та коней. При рівній чисельності військ (близько 23-25 тис. кожне), французи втратили близько 12 тисяч, а в полон потрапив король Франциск I та найкраща частина армії. Іспанці втратили близько 500 чоловік (Ullrich, 1941:86-102, Konstam, 1996:96, Childs, 2002:74-80, Losada, 2006:186-194, Марков, 2007:24-26, Tafilowski, 2007:64-66, Mallet \& Show, 2012:54-61, Войтович, 2018:173-175). Схожою була ситуація і під Оршею, де із значних осіб з війська К. І. Острозького загинув тільки польський достойник Ян Зборовський.

Загалом вперше польову артилерію став використовувати знаменитий венеційський кондотьєр Бартоломео Коллеоні (1400 -1475) iз середини XV ст., до нього подібні спроби були неефективними (Graevenitz, 1906:148, Rendino, 1994:480, Мацюк, 2015:139-150). Щодо ручної вогнепальної зброї, перевагу якої над арбалетом та 
луком довела тільки битва при Босворті (22 серпня 1485 р.), то вперше ефект від масового використання аркебуз зафіксований у згадуваній битві при Павії. У битві при Маріньяно (13-14 вересня 1515 р.), крім артилерії, ефективну роль відіграли арбалетники (Марков, 2007:37-43, Войтович, 2018:170).

Таким чином можна стверджувати, що саме князь Острозький у 1514 р. в битви під Оршею масово застосував польову артилерію та ручну вогнепальну зброю (аркебузи) до чого противник виявився не готовим, що не тільки призвело до великих втрат, але й приголомшило московське військо і зламало його волю до організованого опору.

Зрозуміло, що така подія не могла не захопити сучасників. Величне полотно із зображенням цієї перемоги, завершене близько 1530 p. художником близьким за манерою до Луки Кранаха старшого (1472-1553) (знаходиться в Народному музеї у Варшаві), показували іноземним дипломатам аж до падіння Речі Посполитої наприкінці XVIII ст. Ця картина також $є$ поважним джерелом 3 історії як самої битви так і тогочасних військ (Гуцул, 2009:3-19, Гуиул, 2012:103-110, Нисиt, 2014, Гуиул, 2014:334-349, Нисић, 2015:53-73, Гуиул, 2016:5-22).

Можна не сумніватися, що якби князь К. І. Острозький здобув лише одну таку перемогу, і це давало би право називати його великим полководцем. За своїми масштабами та результатами ця битва перевершує всі відомі битви XVI ст. Сучасники нараховували ще при житті полководця 33 перемоги, а потім навіть і 63 (за А. Кальнофойським, який скопіював епітафію 3 його надгробка) (Kalnofojski, 1638:34). Вигадувати ці перемоги також не було жодної потреби. Зрештою, сліди цих битв все ж проглядаються. Зрозуміло також, що 63 битви віднайти неможливо, позаяк неможливо встановити критерій визначення битви сучасниками. Битва під Оршею і битва 3 ординським загоном, який проривався через кордон з метою захопити ясир або ж втікав з таким ясиром, різні події за масштабами, але можуть бути в рівному ступені названі битвами. А для учасника, який ризикує життям, не буває маленьких битв.

Хроніст Мацей Стрийковський, повідомляючи про перемогу К. І. Острозького над ординцями під Каневом у 1527 р., подав інформацію, що ординців було 34 тис. і в результаті битви було звільнено до 80 тис. бранців з ясиру. У битві взяли участь надвірні війська слуцького князя Юрія Семеновича Олельковича, гродненського старости Юрія Радзивіла, володимирського князя Федора Сангушка, князів Івана та Олександра Вишневецьких, князя 
Олександра Чорторийського, київського воєводи Андрія Немирича та козаки черкаського і канівського старости Остафія Дашковича (Стрийковський, 2011:914-915). За Мартином Бельським (1495 18.12.1575) чисельність ординців була 25 тис. (Kronika Marcina Bielskiego, 1856:855) Шимон Старовольський порівнював перемогу Острозького над татарами під Каневом 3 перемогою під Оршею. Він писав, шо битва тривала цілий день, ординці втратили до 26 тисяч воїнів, було звільнено 40 тис. бранців, після чого переможець знову справив тріумф у Кракові (Starowolski, 1978:185).

Крім великої перемоги під Каневом та розгрому ординців на Ольшаниці (Бевзо, 1970:126), князь Острозький наніс ураження ординцям, які прорвалися до Пінська (Starowolski, 1978:185). Послідовність цих битв за джерелами, що збереглися з'ясувати неможливо. Можливо, один з ординських чамбулів було розбито на Ольшаниці, тоді як основні сили прорвалися аж до Пінська. I вже переслідуючи їх, гетьман Острозький довершив розгром під Каневом.

У 1525 р. “великого князя козаки” доповідали з Азова, що з Криму вийшла рать у 50 тисяч, в числі якої було 15 тисяч “турецької сили" (Дунаев, 1916:82). Тобто в цей період ординські напади провадилися значними силами, які очолював сам хан або його наступник калга-султан. Взагалі, починаючи 31492 р., коли Менглі-Гірей відбудував Кара-Кермен (Очаків), колишню литовську прикордонну фортецю Дашків, та біля Тавані, де ширина рукава Дніпра не перевищувала 500 кроків, спорудив фортецю ІсламКермен (Максимович, 1866:56, Wójcik, 1966:56), ординські напади стали постійними. Польсько-Литовська держава не будувала засічних ліній як Московська держава і не виводила в степ постійні військові контингенти, через що оборона величезного степового кордону практично була відсутньою: ланцюжок невеликих фортець, скоріше замків, не завжди міг оборонити навіть себе. 31497 р. як великий гетьман литовський цю оборону організовував і провадив князь Острозький (Кулаковський, 2011:67-83).

Потрібно зазначити, що практично ніхто 3 дослідників не намагався грунтовно розібратися в бойовій практиці князя Костянтина Івановича Острозького, яка була дуже інтенсивною. До поразки на Ведрощі у 1500 р. він мусив мати вже якусь значну і успішну військову практику. Недаремно його не просто утримували у Вологді, сподіваючись на викуп, а вели перемовини про перехід на російську службу, що він невдовзі і вчинив, отримавши володіння у Московському князівстві (I Софийская летопись, 1853:45). 
Очевидно, було вирішено використати його досвід оборони степового кордону на Україні, і його поставили на чолі одного з полків на московський степовий кордон, де він “в кількох битвах перемогу... ompuмaв" (Starowolski, 1978:184). Коли ж князь невдало спробував втекти, його змусили 18 жовтня 1506 р. дати відповідний запис за порукою митрополита та інших вельмож: “се аз, князь Константин Іванович Острожский, что есми бил челом своему государю в. к. Василию Івановичу за свою вину" (Соловьев, 1989:403, 404).

Князь Острозький досяг успіхів під час літньої кампанії 1506 р. на Степовому кордоні, в кінці якої спробував залишити московську службу. Резонанс від цих перемог був значним, бо князя відносно легко вибачили і повернули до війська. Мусила бути успішною і літня кампанія 1507 р., в кінці якої за князем послабили нагляд, що дозволило йому порозумітися з ординцями (можливо, $з$ деякими 3 них він зустрічався у попередні роки) і з їх допомогою дістатися Литви. 25 вересня 1507 р. князь прибув до Вільна $з$ якимсь татарським відділом. В ті часи і Москва, і Литва охоче брали на військову службу ординців, які отримували шляхетство і зберігали свою належність до ісламу. Воюючи один 3 одним, суперники нерідко домовлялися і брали участь у спільних походах проти Москви (як це робив в той же час, приміром, вже згадуваний Остафій Дашкевич (Зимин, 1972:170). У вічному протистоянні між собою Росія та Литва постійно намагалися залучити на свій бік ординців.

Протягом 1508 р. (до першої, теж успішної, битви під Оршею) різні частини війська, яке князь очолював, здобули і спалили Білу, оволоділи Коропцем та спалили Дорогобуж (Соловьев, 1989:221).

За Шимоном Старовольським, поверненню князеві Острозькому гідності великого гетьмана литовського у 1511 р. передували ще якісь перемоги у сутичках з московським військом (Starowolski, 1978:184). Після перемоги під Оршею у 1514 р. були здобуті Дібровна, Мстиславль і Кричев та обложений Смоленськ. При цьому князь Острозький виступав тільки з 6-тисячним корпусом. Ш. Старовольський згадує також три переможні битви під Слуцьком 3 трьома різними ординськими військами, які відбувалися, очевидно, в різні періоди діяльності князя Острозького (Starowolski, 1978:185).

Невдала Сокальська битва 1519 р. також, вочевидь, не була єдиною того року битвою з ординцями. Причому цей наступ татар відбувався кількома з'єднаннями, які діяли на різних напрямках. 
Спочатку 4 тисячі білгородських татар і 12 тисяч турків вторгнулися на Поділля і спробували взяти Чурилов та Рогатин (Бевзо, 1970:100). А основні сили чисельністю до 80 тисяч (зрозуміло, що джерела перебільшують чисельність ординців) дійшли до Соколя. I схоже, що князь Острозький спочатку рушив до Рогатина, змусивши там ординців зняти облогу, а вже потім поспішив до Соколя, бо у нього залишилося тільки 5 тисяч війська (Бевзо, 1970:125). Можливо, під Рогатином відбулася переможна битва, в якій військо князя Острозького зазнало значні втрати.

Постійна військова служба змусила князя К. І. Острозького навіть відкласти свій другий шлюб з княжною Олександрою Семенівною Слуцькою - князь мусив виступити в похід до Мінська (Акты, относящиеся к истории Западной России, 1848:160).

Відповідаючи за оборону степового кордону, князь К.І. Острозький не міг не оцінити значення ранньої козацької організації, яка самочинно виникла на Поділлі та в Придніпров'ї нижче Канева та Черкас за мовчазної згоди та підтримки прикордонних старост (Предслава Лянцкоронського, Остафія Дашкевича та інших). Варто звернути увагу на два заходи в цьому напрямку. У 1524 р. король доручив річицькому державцеві Сенку Полозовичу і чорнобильському державцю Христофору Кмітичу набрати малий почет чисельністю 1-2 тисячі козаків з виплатою останнім кількох сот кіп литовських грошей (Мемуары, относящиеся к истории Южной Руси, 1896:31). Ці козаки мали сторожити від ординців дніпровські переправи, але через нестачу коштів це військо розійшлося. Тоді на раді панів Литовського сейму 10 грудня 1524 р. у Бересті було розглянуто питання про організацію постійного козацького контингенту на Дніпрі. У записці короля, переданій через біскупа Миколу Вежнгайла, високо оцінювалися результати загону С. Полозовича та Х. Кмітича (Стороженко, 1904:72-74). Ризикну припустити, що всі ці ініціативи короля Сигізмунда Старого були протеговані князем Острозьким, чий військовий авторитет був величезним. Працюючи і воюючи разом з вождями раннього козацтва, такими як О. Дашкевич (який вже по смерті князя у 1533 р. на Пйотрковському сеймі виступив 3 проектом 2-тисячного постійного козацького реєстру з військовою флотилією на дніпровських островах (Kronika Marcina Bielskiego, 1856:1059) і таки добився сеймової постанови про організацію постійного козацького війська, хоча iï так і не реалізували), К. І. Острозький 
не міг залишатися осторонь цих спроб. Тим більше, що саме на період, коли оборона степового кордону була покладена на нього, тобто на 1497-1500, 1511-1530 рр., і припадає раннє формування козацького війська (Черкас, 2006:57-64), основою якого стали вільні, напіввійськові стани (путні бояри, замкові та ординські слуги тощо) та дрібна шляхта. Зближення обох частин Речі Посполитої та панівна ідеологія сарматського міфу все більше перекладали військову службу винятково на шляхетство. Уряд Великого князівства Литовського зайнявся ревізією і перевіркою земельних надань та шляхетства (вивід прав шляхетства 1522, опис війська 1528 р., ревізії замків 1545 та 1552 рр., волочна поміра 1557 р.). Ті категорії бояр, які не змогли довести свого шляхетства, переходили в корпорацію державних селян і мусили платити податки. Люблінська унія 1569 р. поширила на українські землі взамін Литовських статутів польське право, яке взагалі не знало негербової шляхти. „Бояри-шляхта” мусили перетворитися на підданих і змінити шаблю на рало. Частка з них збереглася як „околична шляхта” біля прикордонних замків типу Бару, де їх підтримала місцева адміністрація як єдиний засіб оборони території, чи як пізніша „ходачкова шляхта" на карпатських кордонах (також за мовчазною згодою місцевої адміністрації). Більшість, особливо на Київщині та Брацлавщині, влилися в лави козацтва, принісши з собою до нього лицарські традиції епохи Ягеллонів (Леп'явко, 1990:89-98, Леп'явко, 1993:84-86, Щербак, 1997:180, Войтович, 2017:849-852).

Висновки. В цілому можна стверджувати, що князь Костянтин Іванович Острозький був одним із кращих європейських полководців XVI ст. і, мабуть, таки взяв участь у 63 переможних битвах. Інша річ, що внутрішній стан суспільства Польсько-Литовської держави не давав можливості скористатися плодами таких блискучих перемог, як битва під Оршею чи битва під Каневом. Але ці обставини не залежали від самого князя Острозького. Його високо цінували як прихильники, так і противники. Початки козацької організації також пройшли під його покровительством i, напевно, безпосередньої участі. Все це вимагає детального грунтовного дослідження саме військової діяльності князя К. І. Острозького, яка може дати ще багато цікавої інформації. Серед полководців українського походження небагато таких, яких поряд із князем К. I. Острозьким можна було би поставити в один ряд прославлених європейських полководців свого часу. 


\section{Використані посилання}

Акты, относящчиеся к истории Западной России. 1848. Собранные и изданные Археографической комиссией. Т. 2. 1506-1544. Санкт-Петербург, $405+15+12$ c.

Бевзо Олександр, 1970. Львівський літопис і Острозький літописещь. Київ, $200 \mathrm{c}$.

Быков Николай. 1915. Князья Острожские и Вольнь. Москва, 60 с.

Войтович Леонтій. 1996. Родина князів Острозьких. Записки НТШ. Т. 231. Львів, с. 355-367.

Войтович Леонтій. 2011. Князь Костянтин Іванович Острозький як полководець. Наукові записки Національного університету "Острозька академія”. Вип. 18, Острог, с. 52-62.

Войтович Леонтій, Овсінський Юрій 2017. Завершення переходу до професійних найманих військ. Історія війн і військового мистецтва. Т. 1. Від зачатків військової організації до професійних найманих армій (бл. 3060 до Христа - початок XVI ст.), Харків, с. 739-817.

Войтович Леонтій, Овсінський Юрій. 2017. Українське козацтво. Iсторія війн $i$ військового мистецтва. Т. 1. Від зачатків військової організації до професійних найманих армій (бл. 3060 до Христа - початок XVI ст.), Харків, c. $849-852$.

Войтович Леонтій (ред.) 2018. Італійські війни кінця XV - XVI століття важливий етап еволюції військової справи. Проблеми історії війн $і$ військового мистецтва, Львів, с. 151-180.

Волков Владимир. 2004. Войны и войска Московской Руси, Москва, $576 \mathrm{c}$.

Голубев Стефан. 1877. По поводу двух сообщений о князе Костянтине Ивановиче Острожском. Труды Киевской Духовной Академии. № 4, Киев, с. $182-191$.

Грицкевіч Анатолий. 1993. Аршанская битва 1514. Энияьклопедыя гісторылі Беларусі. Т. 1., Мінск, с. 187.

Грицкевіч Анатолий. 2005. Аршанская битва 1514. Вялікае княства Літоўскае. Энцыклопедыля. Т. 1, Мінск, с. 249.

Гуцул Володимир. 2009. Битва під Оршею (художньо-історичні реалії). Київська старовина. № 5-6, с.3-19.

Гуцул Володимир. 2012. Пам'ятка станкового живопису “Битва під Оршею” 3 Національного музею у Варшаві як джерело до історії козацтва першої третини XVI ст. Нові дослідження пам'яток козацької доби в Украӥні. Вип. 21, ч. 2 , с. $103-110$.

Гуцул Володимир. 2014. “Конно і збройно”. Образи представників руських воєнних еліт на пам'ятці станкового живопису першої третини XVI ст. "Битва під Оршею”: спроба ідентифікації. Średniowiecze Polskie i Powszechne. T. 6(10). Katowice, c. 334-349.

Гуцул Володимир. 2016. “Рицар володіти Єрусалимом достойний”: зброя князя Костянтина Івановича Острозькоо в зображеннях, текстах та артефактах. Острозька давнина. Вип. 5. Остріг, с.5-22.

Домбровский Василий. 1840. Острожская старина. Киевлянин. Кн. 1. Киев, c. $88-89$.

Дунаев Борис. 1916. Пр. Максим Грек и греческая идея на Руси в XVI веке. Москва, 292 с.

Зимин Александр. 1972. Россия на пороге нового времени. Москва, 94 с. 
Зимин Александр. 1972. Россия на пороге нового времени. Очерки политической истории России первой трети XVI в. Москва, 452 с.

Зноско Константин. 1933. Князь Константин Острожский $u$ его деятельность в пользу Православия. Варшава, 290 с.

Каспровский Евгений. 1899. Борьба Василия Ивановича с Сигизмундом I. Сборник Историко-Филологического Общества при Институте кн. Безбородко. Т. 2. Нежин, с. 112-118.

Ковальський Микола. 1998. Етюди з історії Острога. Острог, 288 с.

Крип'якевич Іван. 1951. 3 минулого Каховки. Вісник Академії наук УРСР. № 4. Київ, с. 55-60.

Кром Михаил. 2009. Ещё раз о численности русского войска в XVI в. (По поводу статьи А. Н. Лобина). Studia Slavica et Balcanica Petropolitana. № 1-2, Санкт-Петербург, с. 79-90.

Кулаковський Петро. 2011. Князь Костянтин Іванович Острозький і оборона українських земель від татарської агресії (кінець XV - перша третина XVI ст.), Наукові записки Національного університету “Острозька академія”. Вип. 18 Острог, с. 67-83.

Курбатов Олег. 2009. Отклик на статью А. Н. Лобина. Studia Slavica et Balcanica Petropolitana. № 1-2, Санкт-Петербург, с. 104-119.

Леп'явко Сергій. 1990. Про природу станових привілеїв українського козацтва. Проблеми украӥнської медієвістики. Київ, с. 89-98.

Леп'явко Сергій. 1993. До проблем становлення козацького стану. Другий Міжнародний конгрес украйністів. Львів, 23-28 серпня 1993 р. Доповіді і повідомлення. Історія. Ч. 1. Львів, с. 84-86.

Лихач Евгений. 1902. Острожский Константин Иванович. Русский биографический словарь А. А. Половцова. Т. 12, Санкт-Петербург, с. 457-461.

Лобин Алексей. 2009. К вопросу о численности вооруженных сил Российского государства в XVI в. Studia Slavica et Balcanica Petropolitana. № 12. Санкт-Петербург, с. 45-78.

Лобин Алексей. 2010. К вопросу о численности и составе польсколитовской армии в битве под Оршей в 1514 г. Праблемы интэграц̧ы $i$ инкарпарацылі ў развіциі Цэнтральнфй $і$ Усходняй Еўропь $\check{y}$ перыяд ранняго Нового часу. Мінск, с. 18-42.

Лобин Алексей. 2010. Мифы Оршанской битвы. Родина. № 9. Москва, с. 111-113.

Максимович Михаил. 1866. Письма о князях Острожских к графине А. Д. Блудовой. Киев, 54 с.

Марков Михаил. 2007. История конницы. Кн. 2, Москва, 480 с.

Мацюк Ігор. 2015. Становлення європейських професійних армій: Бартоломео Коллеоні. Військово-науковий вісник. Вип. 24. Львів, с. 139-150.

Мемуары, относящиеся к истории Южной Руси. 1896. Вып. 2. Киев, 455 с.

Мицик Юрій. 2000. Битва під Оршею 1514 року. Україна крізь віки. Київ, c. $133-137$.

Мицько Ігор. 1999. Синодики монастирів як унікальне джерело української генеалогії: князі Острозькі. Лавра. № 2 (4). Львів, с.49-56.

Мордовина Светлана, Станиславский Александр. 1979. Боярские списки последней четверти XVI - начала XVII в. и роспись русского войска 1604 г. Ч. 1, 345 с.; Ч. 2. Москва. 188 с.

Пенской Виталий. 2009. Некоторые соображения по поводу статьи А. Н. Лобина "О численности вооруженных сил Российского государства в XVI в.”. Studia Slavica et Balcanica Petropolitana. № 1-2, Санкт-Петербург, с.91-103. 
Перлштейн Аким. 1852. Несколько слов о княжестве Острогском. Временник об-ва истории и древностей росийских. Кн.14. Исследования. Москва, с.33-48.

Петров Николай. 1879. Две надгробные надписи конца XVII века Константину Івановичу и Константину Константиновичу князьям Острожским. Чтерия в Историческом обществе Нестора Летописиа. Кн. 1. Киев, с. 79-81.

Петрушевич Антон. 1879. Материалы к истории рода кн. Острожских 1879 г. Львівська наукова бібліотека ім. В. Стефаника НАН Украйни. Відділ рукописів. Ф. 77. Ч. 703. Львів.

Романовский Леонид. 1878. О Константине Ивановиче князе Острожском. Труды Третьего Археологического съезда в России. Т. 2. Москва, с. 205-209.

Середонин Сергей. 1891. Известия иностранцев о русских вооруженных силах. Санкт-Петербург, 32 с.

Скрынников Руслан. 1986. Сочиально-политическая борьба в Русском государстве в начале XVII века. Москва, 92 с.

Солдатенко Анатолий. 1993. Польская гусария 1500-1776 гг. Орёл. № 3, с. 17-24.

Соловьев Сергей. 1989. Сочинения. Кн.3. История России с древнейших времен. Т. 5, Москва, 783 с.

Сороколетов Фёдор. 1970. История военной лексики в русском языке XI-XVII вв. Ленинград, 386 с.

I Софийская летопись. 1853. Полное собрание руских летописей. Т. 6, Санкт-Петербург, 324 с.

Стороженко Андрей. 1904. Стефан Баторий и днепровские казаки. Киев, 327 с.

Стрийковський Мацей. 2011. Літопис польський, литовський, жмудський $i$ всієї Pусі. Переклав Р. Івасів, відпов. ред. О. Купчинський, Львів, 1074 с.

Ульяновський Василь. 1992. Пам'ятник Костянтину Острозькому в КиєвоПечерській Лаврі. Украӥнський історичний журнал. № 2, Київ, с. 112-121.

Ульяновський Василь. 1995. Відоме і невідоме 3 біографії та діяльності князя К. І. Острозького. Острозька давнина. Дослідження $і$ матеріали. Т. 1. Львів, с. 24-31.

Ульяновський Василь. 2009. “Славний для всіх часів чоловік”: князь Костянтин Іванович Острозький. Острог, 168 с.

Форум по статье А. Лобина. 2009. Studia Slavica et Balcanica Petropolitana. №1-2, Санкт-Петербург, с. 121-126.

Хорошкевич А. Л. 1988. Герберштейн Сигизмунд. Записки о Московии. Вступ. Пер. с нем. А. И. Малеина и А. В. Назаренко. Москва: Изд-во МГУ, 430 с.

Хэлли Ричард. 1998. Холопство в России 1450-1725. Москва, 712 с.

Черкас Борис. 2006. Українське козацтво наприкінці XV - у першій половині XVI ст. Історія українського козацтва. Нариси у двох томах. Т. 1. Київ, с. 57-64.

Черкас Борис. 2011. Степовий щуит Литви. Украӥнське військо Гедиміновичів. Київ, 144 с.

Щербак Віталій. 1997. Формування козацького стану в Украйні (друга половина XV-середина XVII cm.). Київ, 180 с.

Яковенко Наталя. 2002. Паралельний світ. Дослідження з історії уявлень та ідей в Украӥні XVI-XVII ст.,. Київ, 415 с.

Ярушевич Афанасий. 1896. Ревнитель православия князь Константин Иванович Острожский (1461-1530) и православная литовская Русь в его время. Смоленск, $250 \mathrm{c}$. 


\section{References}

Acta Tomiciana. 1853. Tomus Tertius Epistolarum, Legationum, Responsorum, Actionum et Rerum Gastarum. Serenissimi Principis Sigismundi Primi, Regi Poloniae et Magni Ducis Lithuanie. T. 2. Poznań,, 624 p.

Boniecki Adam. 1883. Poczet rodów w Wielkim Księstwe Litewskim w XV i XVI wieku. Warszawa, 425+XLIX s.

Charkiewicz Walerian. 1934. Scypion Ruski Konstanty Iwanowicz, ksiaże Ostrogski wielki hetman litewski, wojewoda trocki, kasztelan wileński, marszalek ziemi wotyńskiej, starosta tucki, bracławski, winnicki. Wilno, $240 \mathrm{~s}$.

Childs John. 2002. Warfare in the Seventeenth Century. London, 240 p.

Dundulis Bronius. 1971. Lietuvos uzsienio politika XVI a. Vilnius, $308 \mathrm{~s}$.

Herbst Stanisław, Walicki Michał. 1949. Obraz bitwy pod Orszạ. Dokument historii sztuki i wojskowości. Rozprawy Komisji Historii Kultury $i$ Sztuki Towarrzystwa Naukowego Warszawskiego. Warszawa, s. 33-68.

Hucuł Vladimir. 2014. Obraz Bitwa pod Orcza - propaganda dworska czy epos rycerski? Riha. Journal 0092, 3 July 2014.

Hucuł Wołodymyr, Nagielski. N. (red.) 2015. Zachodnioeuropejskie korzenie husarii orszańskiej. Bitwa pod Orszq. Warszawa, s. 53-73.

Genealogia domu Ostrogskich. 1871. Wilno, 128 s.

Górski Konstanty. 1890. O rozwoju sztuki wojennej w Polsce w wieku XV. Biblioteka Warszawska. T. 2. Warszawa, 425 s.; T. 3. Warszawa, 1890, 398 s.

Graevenitz George von. 1906. Gattamelata (Erazmo da Narni) und Colleoni. Leipzig, $148 \mathrm{~s}$.

Kalnofojski Athanasius. 1638. Tepatoyргнma lubo cuda, które były tak w samym swięntocudownym Monastyru pieczarskim Kijowskim, jako y w obudwu swiętych Pieczarach. Kijów, 356 s.

Kempa Tomasz. 2003. Dzieje rodu Ostrogskich. Toruń, 194 s.

Konstam Angus. 1996. Pavia 1525: The Climax of the Italian Wars. Oxford, 96 p.

Kronika Marcina Bielskiego. 1856. T.2. Sanok, s. 700-1222.

Lietuvos metrika. Книга записей № 11 (1518-1523) 1997. Подг. Артурас Дубонис. Вильнюс, 228 с.

Lewicki Kazimierz. 1938. Ksiạżęta Ostrogscy w służbie Rzeczypospolitej. Rocznik Wotyński. Równe, s. 1-66.

Lindner Rainer. 1999. Historiker und Herrschaft Nationsbildung und Geschichtspolitik im Weisrusland im 19. und 20. Jahrhundert. München, 536 s.

Losada Joan Carlos. 2006. Batallas Decisivas de la Historia de Espan̆a. Madrid, 353 p.

Mallet Michael, Show Christine. 2012. The Italian Wars 1494-1559. Harlow, 392 p.

Nagielski Mirosław (red.) 2015. Bitwa pod Orsza. Warszawa, 242 s.

Niesiecki Kasper. 1841. Herbarz Polski. Wyd. i oprac. J. N. Bobrowicz. T. 7. Lipsk, 582 s.

Ochmański Jan. 1960. Organizacja obrony w Wielkim Księstwie Litewskim przed napadami Tatarów Krymskich w XV-XVI wieku. Studia i Materiały do Historii Wojskowości. T. 5.Warszawa, s. 349-398.

Paprocki Bartosz. 1858. Herby rycerstwa Polskiego, przez Bartosza Paprockiego zebrine $i$ wydane r. p. 1584. Wyd. K. J. Turowskiego. Kraków, 964+CLXVII+12 s.

Rendino Claudio. 1994. I capitani di ventura. Roma, 480 p.

Rulikowski Edward, Radzimiński Zigmund Luba. Kniaziowie na Ostrogu Ostrogcy (Kraków, 1880), 195 s.

Rulikowski Edward, Radzimiński Zigmund Luba. Kniaziowie i szlachta. Kraków, b. r., 3-40. 
Sarnicii Stanislai. 1587. Annales sive de origine et rebus gestis Polonicae et Lituanorum libri octoa. Cracoviae, $412 \mathrm{p}$.

Smith Dianne L. 1993. Muscovite Logistics, 1462-1598. Slavonic and East European Review. Vol. 71. Nr. 1, p. 35-65.

Spieralski Zdzisław, Sikorski Janusz (red.) 1965. Bitwa pod Orszạ (1514). Zarys dziejów wojskowości polskiej do roku 1864. T. 1. Do roku 1648. Warszawa, p. 331-337.

Starowolski Szymon. 1978. Wojownicy sarmaccy. Warszawa, 294 s.

Strahl Philipp Carl, Hermann Ernst. 1846. Geschichte des russischen Staates. Aus. 3. Hamburg, $830 \mathrm{~s}$.

Tafilowski Piotr. 2007. Wojny włoskie 1494-1559. Zabrze, 448 s.

Ullrich Florian. 1941. L'Art de La Guerre. Paris, 402 p.

Wojtkowian Zigmund. 1979. Ostrogski Konstantin Iwanowycz. Polski Slownik Biograficzny. T. 24/3. Warszawa, p. 486-489.

Wolff Jozef. 1895. Kniaziowie Litewsko-Ruscy od konca czternastego wieku. Kraków, 698 s.

Wójcik Zbigniew. 1966. Dzikie pola w ogniu (o kozaczyzni w dawnej Rzeczy Pospolitej). Warszawa, 284 s.

\section{Leontii Voitovych \\ MILITARY ACTIVITY OF THE DUKE KOSTIANTYN IVANOVYCH OSTROZKYI}

The article is devoted to the evaluation of intense activity of duke Kostiantyn Ivanovych Ostrozkyi, foremost as a combat leader. Main estimations are considered by the contempoeanes of his figure. Basic attention is paid to the victories obtained under his command, in particular in battles of Orsha (1514) and Kaniv (1527).

By means of different manipulations concerning the quantity of troops of both parties near Orsha, new Russian historiography attempted to diminish a role and achievements of Kostiantyn Ivanovych Ostrozkyi as a combat leader. In-depth consideration of these attempts takes into account the sources, as well as the reasons of defect of the Moscow army and its severe lossesl. It is determined that a main factor that resulted in severe losses and defect was the massed application of the field artillery in combination with the volleys of arkebusiers. The emeny was unprepared for this and broke his will to the organized resistance. Herein Kostiantyn Ivanovych Ostrozkyi came forward to one of the first right behind Venetian condottiere of Bartolomeo Colleoni. The battleof Orsza was one of the first along with the battles of Pavia and Marignano, where the field artillery and arbalesters played a leading role. Great attention was paid to the resonance caused by this victory in Europe.

Special attention has been given to the activity of duke Kostiantyn Ivanovych Ostrozkyi as south steppes defense organizer from the Krimean Khanate. A reasonable hypothesis relates to the role of Duke in forming of the early Kozatstvo. It is concluded that in relation to the recessity of the further deteiled deep research exactly of military activity of duke Kostiantyn Ivanovych Ostrozkyi, many interesting information can be gained.

Among the historical figures of Ukraine the duke Kostiantyn Ivanovych Ostrozkyi takes special place both politician and renowned combat leader of his era.

Keywords: Kostiantyn Ivanovych Ostrozkyi, combat leader, Orsha, Kaniv, Cossacks. 